X. ZHANG, G. LU, M. SUN, M. MAHANKALI, Y. MA, M. ZHANG, W. HUA, Y. HU,

Q. WANG, J. CHEN, G. HE*, X. QI*, W. SHEN*, P. LIU*, G. CHEN* (NANKAI UNIVERSITY, TIANJIN AND NATIONAL INSTITUTE OF BIOLOGICAL SCIENCES, BEIJING, P. R. OF CHINA; UNIVERSITY OF PITTSBURGH, CALIFORNIA INSTITUTE FOR BIOMEDICAL RESEARCH,

LA JOLLA, AND THE PENNSYLVANIA STATE UNIVERSITY, UNIVERSITY PARK, USA)

A General Strategy for Synthesis of Cyclophane-Braced Peptide Macrocycles via Palladium-Catalysed Intramolecular $\mathrm{sp}^{3} \mathrm{C}-\mathrm{H}$ Arylation

Nat. Chem. 2018, 10, 540-548.

\section{Synthesis of Cyclophane-Braced Peptide Macrocycles}
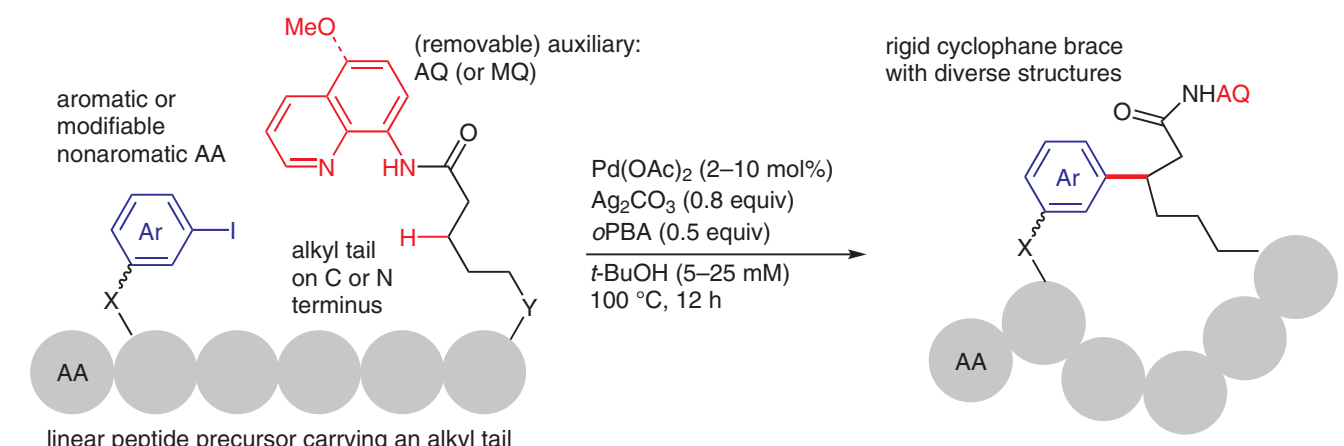

linear peptide precursor carrying an alkyl tail

Macrocyclization of peptides at iodinated aromatic amino acids:

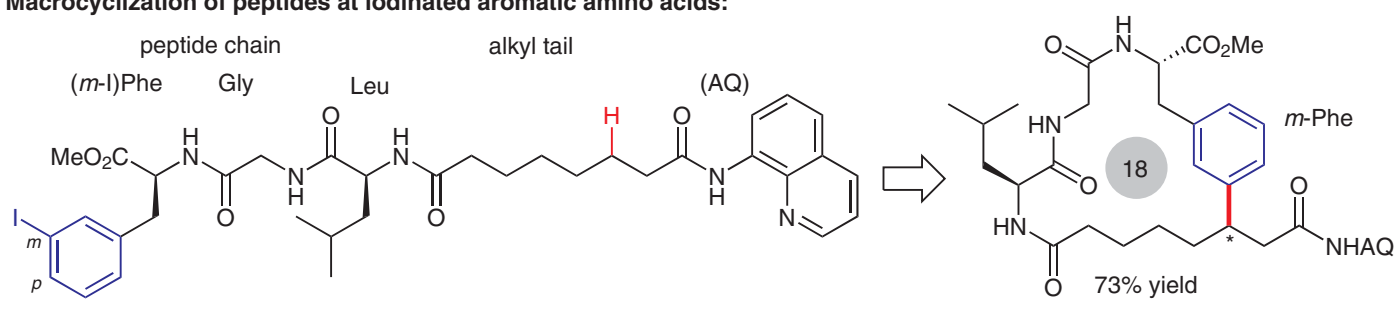

Macrocyclization of peptides at modifiable nonaromatic amino acids:

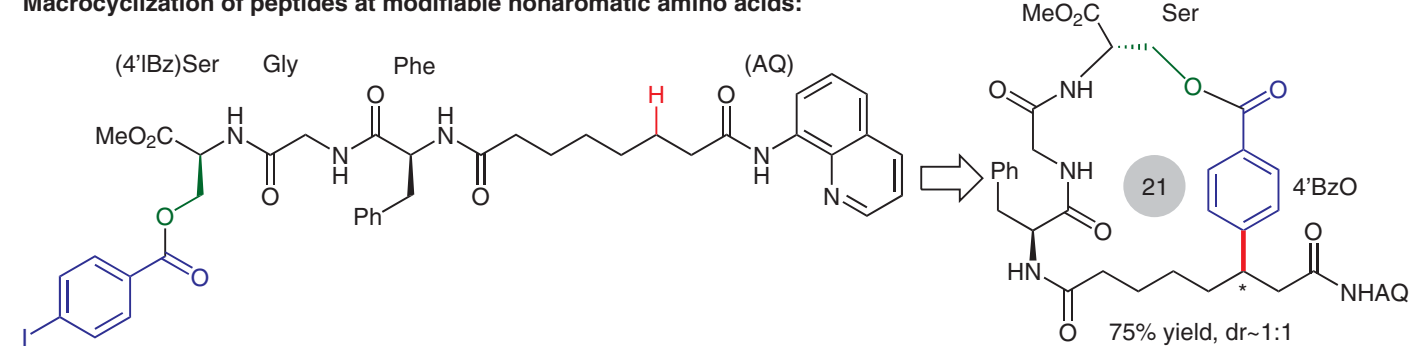

Synthesis of small-sized cyclophanes:<smiles>CC(=O)C(Cc1ccc(I)cc1)NC(=O)CCCCCC(=O)Nc1cccc2cccnc12</smiles>

Category

Peptide Chemistry

Key words

palladium catalysis

C-H arylation

cyclophanes

macrocycles

peptide macrocycles
Significance: New efficient methods for the intramolecular cyclization of peptides are important in terms of the development of drugs based on cyclic peptides. The authors report a powerful method for constructing new types of peptide macrocycles through palladium-catalyzed, aminoquinolinedirected, intramolecular $\mathrm{C}\left(\mathrm{sp}^{3}\right)-\mathrm{H}$ arylation reactions.

SYNFACTS Contributors: Hisashi Yamamoto, Takahiro Sawano Synfacts 2019,15(03), 0317 Published online: 15.02.2019 DOI: 10.1055/s-0037-1611466; Reg-No.: H00419SF
Comment: The cyclization of readily accessible linear peptide precursors selectively proceeds at side chains of either aromatic or modified nonaromatic amino acids units to provide a variety of cyclophane-braced peptide macrocycles containing small-sized cyclophanes. 